The Church of Greece Under Axis Occupation 
This page intentionally left blank 
WORLD WAR II: THE GLOBAL, HUMAN, AND ETHICAL DIMENSION

G. Kurt Piehler, series editor 
This page intentionally left blank 


\section{The Church of Greece Under Axis Occupation}

\section{Panteleymon Anastasakis}




\section{Copyright (C) 2015 Fordham University Press}

All rights reserved. No part of this publication may be reproduced, stored in a retrieval system, or transmitted in any form or by any means - electronic, mechanical, photocopy, recording, or any other-except for brief quotations in printed reviews, without the prior permission of the publisher.

Fordham University Press has no responsibility for the persistence or accuracy of URLs for external or third-party Internet websites referred to in this publication and does not guarantee that any content on such websites is, or will remain, accurate or appropriate.

Fordham University Press also publishes its books in a variety of electronic formats. Some content that appears in print may not be available in electronic books.

Visit us online at www.fordhampress.com.

Library of Congress Cataloging-in-Publication Data

Anastasakis, Panteleymon, 1977-

The Church of Greece under Axis occupation / Panteleymon Anastasakis. - First edition. pages $\mathrm{cm}$. - (World War II : the global, human, and ethical dimension)

Includes bibliographical references and index.

ISBN 978-o-8232-6199-4 (cloth : alk. paper)

1. Orthodox Eastern Church-Clergy-Greece. 2. Orthodox Eastern Church-Greece.

3. Greece-History-1917-1944. 4. World War, 1939-1945-Greece. I. Title.

BX618.A515 2015

$281.9^{\prime} 49509044-\mathrm{dc} 23$

2014030500

Printed in the United States of America

$\begin{array}{llllllll}17 & 16 & 15 & 5 & 4 & 3 & 2 & 1\end{array}$

First edition 
To my parents, George and Helen Anastasakis 
This page intentionally left blank 